\title{
EFFECT OF LOCATION AND PLANTING DATE ON BOTTLE GOURD (LAGENARIA SICERARIA L.) PRODUCTIVITY AT DESERT SOILS
}

\author{
Soubeih, Khaled A. \\ Department of Plant Production, Desert Research Center, El- \\ Matareya, Cairo, Egypt \\ E-mail: soubeihk@yahoo.com
}

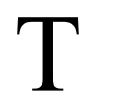

wo field experiments were carried out during the summer seasons of 2008 and 2009 to investigate the effect of two various agricultural sites (Ras Sudr region, South Sinai and Al-Maghara region, Middle Sinai) and four sowing dates (March $15^{\text {th }}$, April $1^{\text {st }}$, April $15^{\text {th }}$ and May $1^{\text {st }}$ ) on growth, flowering, fresh fruits, seed yields, accumulated heat units and nutritional values of bottle gourd Egyptian variety. The results revealed that the emergence period $\left(E_{p}\right)$, foliage fresh weight after 120 days from sowing, absolute growth rate (AGR), number of female flowers, average fresh fruit weight and carbohydrates content of fresh fruits were significantly influenced by agricultural sites. Delaying planting dates increased fresh and dry foliage weight of samples taken after 30 and 75 days from sowing date and decreased flowering period $\left(\mathrm{F}_{\mathrm{p}}\right)$, while the earlier sowing dates increased fresh and dry foliage weight after 120 days from sowing, (AGR) and flowering characteristics enhanced in addition to increase seed and fresh yield and its contents of nitrogen, phosphorus and protein. As regard, the interaction among studied factors $E_{p}$ recorded the significant latest value in Al-Maghara on May $1^{\text {st }}$, also, foliage fresh and dry weight significantly were affected with interaction and the highest value of (AGR) was recorded in Ras Sudr on March $15^{\text {th }}$, while the earlier sowing dates whether in Ras Sudr or Al-Maghara significantly increased flowering characteristics, fruiting period, fresh fruits and seeds yield characteristics and the content of N, $\mathrm{P}$ and protein. Correlation and regression relationship revealed that high significant negative correlation between $\left(\mathrm{F}_{\mathrm{p}}\right)$ and the accumulated dry mater after 30 days of sowing. The regression coefficient indicated that for each increase of one gram dry matter, $\left(F_{p}\right)$ correspondingly decreased by 1.52 days, the same trend was observed between the average of weight and number of fresh fruits, where each decrease of 9.12 gram of each fruit/plant led to correspondingly increase one fruit. On the contrary, the correlation was significantly positive between number of female flowers and foliage dry weight after 120 days from sowing, number of 
fresh fruit and female flowers / plant besides fresh fruits yield ton/fed and number of fruits/plant. Base temperature of bottle gourd locale cultivar was $10.88^{\circ} \mathrm{C}\left(51.58^{\circ} \mathrm{F}\right)$ and the thermal times for $75 \%$ of plants emergence, the first flower, last fresh fruit and complete $1 \pm 20$ y mature phase are $57.6 \pm 6.6,399.7 \pm 46.6,1625 \pm 59.2$ and 2476.0 .8 heat units, respectively. So, it could produce the highest fresh fruits and seed yields when plants are sowing on March $15^{\text {th }}$.

Keywords: agricultural sites, sowing date, bottle gourd (Lagenaria siceraria), growth, yield, nutritional value

Food security has become a critical issue in rural Africa due to the possible effects of climate change, reduction in arable land, as well as increase in human population and poverty.

Bottle gourd is one of the species early domesticated by humans Erickson et al. (2005), Clarke et al. (2006) and Schlumbaum and Vandorpe (2012), and it is growing in many of the tropical and semi-tropical climate countries. It thrives well in hot and humid conditions. Egypt climate is varying from region to other. However, it is not known among food crops in Egypt Bottle gourd (Lagenaria siceraria (Molina) Standl.), also known as calabash gourd or white flowered gourd plant. It is a member of the Cucurbitaceae family, Cucurbitoideae subfamily, and Benincaseae tribe (Richardson, 1972). Bottle gourd or Aliqten in Arabic, mentioned in the Holy Quran (Saaffat verse 146) is growing over a wide range of soils, but sandy loam soil with good drainage and $\mathrm{pH}$ near 6.5 is desirable. Bottle gourd grows well within the tropical and temperate regions of Africa, Indo-Malayasia, the Americas and neo-tropics. Chimonyo and Modi (2013). observed good adaptation in high elevated sub-tropical, tropical and temperate climates, as well as low-lying semi-arid to arid climates. Bottle gourd grows well in areas with rainfall of between 400-1500 mm per annum; however, moderate, rather than excessive soil water is desired for good harvest (Haque et al., 2009). Therefore, bottle gourd is intolerant of water logging. According to Chimonyo and Modi (2013), bottle gourd grows well under warm temperatures $\left(25-35^{\circ} \mathrm{C}\right)$. Under frost-free, low temperature conditions, also, bottle gourd grow well, provided the plants have attained sufficient vegetative growth before the onset of cool weather. Optimum germination temperature is between 20 and $25^{\circ} \mathrm{C}$. Temperatures below $15^{\circ} \mathrm{C}$ and above $35^{\circ} \mathrm{C}$ reduce the germination rate. This cucurbit has been observed to do well in a range of soils, which are fertile and well-aerated. Its use as a vegetable, fruits are varying greatly in shape, size and color, also fruits have high nutritional value and contain alkaloid components. Seeds are used for oil and protein (Chimonyo and Modi, 2013). A lot of information is known on the medicinal aspects of bottle gourd (Milind and Satbir, 2011). Bottle gourd is characterized with vigor growth, dioecious and andromonoecious sex forms bearing hermaphrodite flowers also exist in 
wild, male flowers appear first, the sex ratio (male: female) for bottle gourd is high.

Flowering is highly sensitive to photoperiod. Short days, coupled with low night temperatures and high relative humidity promoted the development of male flowers, while the reverse promotes female flowers (Haque et al., 2009). Agronomic practices that promote the production of more female flowers than male flowers, they could increase yield. Also, Haque et al. (2009) observed less seeds set due to the reduction of pollen. Therefore, it is important to determine the optimum ratio of male and female flowers to optimize fruit and seed set. Cucurbit flowering behavior varies with cultivar, climatic conditions, and cultural practices (Deshpande et al., 1979). The average ratio of staminate to pistillate flowers in monoecious lines throughout the flowering period is typically 50:1 (Rasco and Castillo, 1990), but ratios can vary dramatically (i.e., 9:1 to 48: 1) (Dey et al., 2005). While, long photoperiods cause staminate flowers to bloom up to 2 weeks earlier than pistillate flowers, short days have the reverse effect (Huyskens et al., 1992). Nearly $90 \%$ of pistillate flowers borne on the first 40 nodes, and majority of them mature at nodes 21 to 30 . Judicious pruning of lower laterals stimulates subsequent lateral branch production, which in turn tends to increase the total number of flowers per plant (Rasco and Castillo, 1990). Bees are important pollinators of bottle gourd in India (Behera 2004).

\section{MATERIALS AND METHODS}

Two field experiments were conducted out at Research Stations of Ras Sudr, South Sinai and Al-Maghara, central Sinai during two consecutive summer seasons of 2008 and 2009, to study the effect of the agricultural sites and sowing dates on bottle gourd (Lagenaria siceraria) local cultivar.

Two different thermal agricultural sites, Ras Sudr, South Sinai and AlMaghara in Middle Sinai were used as the first investigate factor. The second factor was four sowing dates; i.e. March $15^{\text {th }}$, April $1^{\text {st }}$, April $15^{\text {th }}$ and May $1^{\text {st }}$. The transactions were distributed randomly in the factorial experiment designated split plot, so that the sites were in the main plots and the sowing dates comprised sub plots within four replicates.

The experimental soil was processed signatories and plowed twice orthogonally then at one meter distance, parallel grooves were made with about $50 \mathrm{~cm}$ depth. The sheep old degradable organic manure at rate of 25 $\mathrm{m}^{3} /$ fed mixed with slow release calcium superphosphate $\left(15.5 \% \mathrm{P}_{2} \mathrm{O}_{5}\right)$ at rate of $250 \mathrm{~kg} / \mathrm{fed}$ were added to the grooves and covered with soil, drip irrigation hoses (GR $4 \mathrm{l} / \mathrm{h}$ ) extended above it. There were 16 plots in every site, each plot $21 \mathrm{~m}^{2}$ ( $3 \mathrm{~m}$ width $\mathrm{x} 7 \mathrm{~m}$ length), 1 meter between ridges and $30 \mathrm{~cm}$ apart between plants. Bottle gourd seeds were sown with a handle cone seeder at 70 seeds per plot with a target depth of $3 \mathrm{~cm}$. Drip irrigation system was used 30 
minutes daily to emergency completed, 45 minutes per day until the flowering start and then for 60 minutes every day to the rest of the evening with plant age. Common cultural practices were followed i.e., fertigation with mineral fertilizers $\left(300 \mathrm{~kg} \mathrm{NH}_{4} \mathrm{NO}_{3}, 33.5 \% \mathrm{~N} /\right.$ fed and $100 \mathrm{~kg} \mathrm{~K}_{2} \mathrm{SO}_{4}, 49.5 \% \mathrm{~K}_{2} \mathrm{O} /$ fed divided as plants need during growing season) and disease, insects and weeds control.

The methods described by Piper (1950) and Jackson (1962) were used to estimated physical and chemical analysis of the experimental soil respectively, while irrigation water analysis was determined by methods of Richards (1954) as shown in tables (1 and 2). Also, monthly temperature data during both growing seasons were tabulated in table (3).

Table (1). Mechanical properties of experimental soils.

\begin{tabular}{cccccccc}
\hline \multirow{2}{*}{$\begin{array}{c}\text { Studied } \\
\text { seasons }\end{array}$} & \multirow{2}{*}{ Location } & \multirow{2}{*}{$\mathbf{C a ~ C O}_{3}$} & \multicolumn{2}{c}{ Sand } & \multirow{2}{*}{ Silt } & \multirow{2}{*}{ Clay } & \multirow{2}{*}{ Class texture } \\
\cline { 2 - 5 } & & \multicolumn{5}{c}{ Coarse } & \multicolumn{2}{c}{ Fine } & & \\
\hline $\begin{array}{c}\mathbf{1}^{\text {st }} \\
\text { season }\end{array}$ & Ras Sudr & 56.9 & 52.3 & 27.6 & 6.1 & 13.8 & Sandy Loam \\
\cline { 2 - 6 } & Al-Maghara & 12.5 & 45.0 & 50.0 & 4.0 & 1.0 & Sandy \\
\hline $\begin{array}{c}\mathbf{2}^{\text {nd }} \\
\text { season }\end{array}$ & Ras Sudr & 55.2 & 51.9 & 27.6 & 6.9 & 13.3 & Sandy Loam \\
\cline { 2 - 6 } & Al-Maghara & 11.2 & 42.6 & 52.4 & 3.5 & 1.2 & Sandy \\
\hline
\end{tabular}

Table (2). Chemical analysis of experimental soils and irrigation water of Ras Sudr and Al-Maghara.

\begin{tabular}{|c|c|c|c|c|c|c|c|c|}
\hline \multirow{3}{*}{$\begin{array}{l}\text { Type of } \\
\text { analysis }\end{array}$} & \multicolumn{4}{|c|}{$1^{\text {st }}$ season } & \multicolumn{4}{|c|}{$2^{\text {nd }}$ season } \\
\hline & \multicolumn{2}{|c|}{ Soil analysis } & \multicolumn{2}{|c|}{ Water analysis } & \multicolumn{2}{|c|}{ Soil analysis } & \multicolumn{2}{|c|}{ Water analysis } \\
\hline & Loc. 1 & Loc. 2 & Loc. 1 & Loc. 2 & Loc. 1 & Loc. 2 & Loc. 1 & Loc. 2 \\
\hline $\mathrm{pH}$ & $8.00 *$ & $7.93 *$ & $8.16^{*}$ & $7.14 *$ & $8.07 *$ & $7.88 *$ & $8.32 *$ & $7.26^{*}$ \\
\hline $\mathrm{EC} \mathrm{dS} \backslash \mathrm{m}$ & 4.5 & 2.4 & 4.2 & 4.0 & 4.7 & 2.8 & 4.5 & 4.1 \\
\hline \multicolumn{9}{|c|}{ Anions $\left(\mathbf{M m o l}_{\mathbf{c}} \backslash \mathbf{L}\right)$} \\
\hline $\mathrm{CO}_{3}^{--}$ & 0.0 & 0.0 & 0.0 & 0.6 & 0.0 & 0.0 & 0.0 & 1.0 \\
\hline $\mathrm{HCO}_{3}^{-}$ & 6.2 & 1.2 & 1.8 & 2.8 & 6.0 & 1.0 & 1.7 & 3.0 \\
\hline $\mathrm{Cl}^{-}$ & 29.2 & 21.0 & 23.7 & 26.1 & 30.8 & 20.0 & 25.7 & 27.5 \\
\hline $\mathrm{SO}_{4}^{--}$ & 8.8 & 8.2 & 14.6 & 12.3 & 9.6 & 7.0 & 15.7 & 10.0 \\
\hline \multicolumn{9}{|c|}{ Cations $\left(\mathbf{M m o l}_{\mathbf{c}} \backslash \mathbf{L}\right)$} \\
\hline $\mathrm{Ca}^{++}$ & 23.0 & 7.2 & 3.1 & 8.8 & 24.0 & 6.0 & 3.4 & 8.5 \\
\hline $\mathrm{Mg}^{++}$ & 9.2 & 7.7 & 12.5 & 9.5 & 11.0 & 8.0 & 12.5 & 9.3 \\
\hline $\mathrm{K}^{+}$ & 0.8 & 1.3 & 0.4 & 0.1 & 1.4 & 1.4 & 0.1 & 0.2 \\
\hline $\mathrm{Na}^{+}$ & 11.4 & 13.6 & 24.0 & 22.1 & 10.5 & 12.6 & 28.1 & 23.5 \\
\hline
\end{tabular}

Egyptian J. Desert Res., 66, No. 2, 351-372 (2016) 
Table (3). Temperature data.

\begin{tabular}{|c|c|c|c|c|c|c|c|c|c|c|c|c|}
\hline \multirow{3}{*}{ Month } & \multicolumn{6}{|c|}{$1^{\text {st }}$ season } & \multicolumn{6}{|c|}{$2^{\text {nd }}$ season } \\
\hline & \multicolumn{3}{|c|}{ Ras Sudr } & \multicolumn{3}{|c|}{ Al-Maghara } & \multicolumn{3}{|c|}{ Ras Sudr } & \multicolumn{3}{|c|}{ Al-Maghara } \\
\hline & Day & Night & Mean & Day & Night & Mean & Day & Night & Mean & Day & Night & Mean \\
\hline March & 21.5 & 11.2 & 16.4 & 24.0 & 10.2 & 17.1 & 22.7 & 12.4 & 17.6 & 25.2 & 11.4 & 18.3 \\
\hline April & 24.3 & 14.6 & 19.5 & 29.2 & 13.4 & 21.3 & 25.5 & 16.5 & 21.0 & 30.4 & 14.6 & 22.5 \\
\hline May & 30.6 & 17.8 & 24.2 & 34.1 & 14.2 & 24.2 & 32.7 & 18.0 & 25.4 & 35.3 & 15.4 & 25.4 \\
\hline June & 38.6 & 17.2 & 27.9 & 38.4 & 15.0 & 26.7 & 42.1 & 19.5 & 30.8 & 39.6 & 16.2 & 27.9 \\
\hline July & 40.5 & 22.1 & 31.3 & 43.2 & 16.4 & 29.8 & 46.1 & 23.5 & 34.8 & 44.4 & 17.6 & 31.0 \\
\hline August & 39.7 & 23.0 & 31.4 & 42.3 & 18.2 & 30.3 & 43.9 & 23.7 & 33.8 & 43.5 & 19.4 & 31.5 \\
\hline September & 35.8 & 22.2 & 29.0 & 37.4 & 16.8 & 27.1 & 40.0 & 23.0 & 31.5 & 38.6 & 18.0 & 28.3 \\
\hline October & 33.4 & 20.4 & 26.9 & 31.4 & 15.6 & 23.5 & 35.6 & 21.5 & 28.6 & 32.6 & 16.8 & 24.7 \\
\hline
\end{tabular}

Meteorological Laboratory, Desert Research Center

\section{Data Recorded}

\subsection{Germination of seeds}

Germinated seeds were counted daily to determine the following:
a. Emergency period $\left(E_{p}\right)=$ number of days required for $75 \%$ of sown bottle gourd seeds germinated per plot.
b. Emergence $\%=\frac{\text { No. of germinated seeds } / \text { plot }}{\text { Stander number of seeds } / \text { plot }} \times 100$
c. Survival ratio $=$ $\frac{\text { No. of life normal plants after } 30 \text { days from sowing/plot }}{\text { No. of stander plants } / \text { plot }} \times 100$

d. Base temperature $\left(T_{b}\right)$ was determined using liner regression analysis (Arnold, 1959) depending on mean monthly temperature in $\mathrm{X}$ axis and rate of growth in $\mathrm{Y}$ axis. The last item is 100/ duration from seed sowing to first flower.

Thermal time $(\mathrm{Tt})=\frac{\text { Maximum temperature }+ \text { Minimum temperature }}{2}-\mathrm{Tb}$

during determined period of were emergence, flowering, fresh fruit yield and seed yield.

\subsection{Vegetative growth}

A random five plants of bottle gourd were taken after 30,75 and 120 days from sowing to estimate foliage fresh and dry weight, determined as described in A.O.A.C. (1990). Also, absolute growth rate (AGR) was determined according to the equation described by Radford (1967) as following:

$$
\operatorname{AGR}(g / \text { day })=\frac{\mathrm{W} 3-\mathrm{W} 1}{\mathrm{~T} 3-\mathrm{T} 1}
$$


Where:

$\mathrm{W}_{1}=$ plant dry weight of the first sample (g/plant). $\mathrm{W}_{3}=$ plant dry weight of the third sample (g/plant). $\quad \mathrm{T}_{1}=$ first sample time (days). $\mathrm{T}_{3}=$ third sample time (days).

\subsection{Flowering}

After emergence, 10 randomly seedlings were marked to account the number of days from seed sowing to the first flower (flowering period- $\mathrm{F}_{\mathrm{p}}$ ) and the number of male $\left(\delta^{\Uparrow}\right)$ and female $(+)$ flowers to calculate the sexual ratio and fruit set ratio.

\subsection{Yield and its components}

Each experimental plot split was divided into two equal parts, the first one for determination the fresh yield and its component, while the second part was to assay the mature yield and its components.

\section{a. Fresh fruit yield and its components}

Fresh fruit yield was harvested every three days to determine the following characteristics:

- No. of days to last fresh fruit

- No. of fresh fruits / plant

- Average of fresh fruit weight (g)

- Fruit yield / half plot $\left(10.5 \mathrm{~m}^{2}\right)(\mathrm{kg})$

- Fresh fruit yield ton/fed

$$
\text { Fruit set }(\%)=\frac{\text { Number of fruit } / \text { plant }}{\text { Number of female flower } / \text { plant }} \times 100
$$

\section{b. Mature yield and its component}

- No. of days to mature phase

- Average of seeds no./plant

- Average of 100 seeds weight $(\mathrm{g})$

- Half plot $\left(10.5 \mathrm{~m}^{2}\right)$ seeds yield $(\mathrm{kg})$

- Weight of seeds (g/plant)

- Seeds yield (ton/fed)

\subsection{Chemical composition}

Nitrogen, phosphorus and potassium were determined in representative samples of fruit dry matter according to the methods used by Peach and Tracey (1959), Frie et al. (1964) and Brown and Lilliland (1964) for N, P and $\mathrm{K}$, respectively. Total carbohydrates percentage of fresh fruit was determined according to the method described by Chaplin and Kennedy (1994).

\section{Statistical Analysis}

The obtained data were statistically analyzed according to Gomez and Gomez (1984).

\section{RESULTS AND DISCUSSION}

\section{Effect of Location and Planting Date on Germination}

Data in table (4) show that there were significant differences among the tested sites and planting dates and their interaction on the number of days bottle gourd required for $75 \%$ of seeds emerges (emergence period $-E_{p}$ ). The $\mathrm{E}_{\mathrm{p}}$ significantly decreased at Ras Sudr region and when planting delayed as separated treatments. While the interaction between Al-Maghara region and 
last planting date May $1^{\text {st }}$ led to significantly decrease $\left(E_{p}\right)$ values compared with other interaction treatments. The results were similar in both growing seasons. The results agree with those obtained by Dubey et al. (2011), Sawicka and Marczak (2011), Darabi (2013) and Gomaa (2014). These results may be due to the temperature gradual increase throughout the agricultural sites and planting dates from 16.5 or $17.0^{\circ} \mathrm{C}$ on March to 23.5 or $24.1^{\circ} \mathrm{C}$ on May, at Ras Sudr and Al-Maghara, respectively. This increasing in air temperature enhanced seeds absorption of soil solution and embryo development activation, in turn, fast germination. Hossain et al. (2012) found that the duration needed for wheat plants to full germination is longer when plants exposed to high temperature stress than that around the optimal temperature.

Table (4). Effect of agricultural location and sowing date on some germination measurements of bottle gourd (Lagenaria siceraria) during summer of 2008 and 2009 seasons.

\begin{tabular}{|c|c|c|c|c|c|c|c|c|c|c|c|}
\hline \multirow{2}{*}{\multicolumn{2}{|c|}{ Treatments }} & \multicolumn{2}{|c|}{ No. P / plot Ec. } & \multicolumn{2}{|c|}{$\begin{array}{l}\text { Emergence } \\
\text { period }\left(\mathrm{E}_{\mathrm{p}}\right)\end{array}$} & \multicolumn{2}{|c|}{$\begin{array}{c}\text { Emergency } \\
\% \\
\end{array}$} & \multicolumn{2}{|c|}{$\begin{array}{c}\text { Survival period } \\
\left(\mathrm{S}_{\mathrm{p}}\right)\end{array}$} & \multicolumn{2}{|c|}{ Survival ratio } \\
\hline & & $1^{\text {st }} \mathrm{S}$ & $2^{\text {nd }} S$ & $1^{\text {st }} \mathrm{S}$ & $2^{\text {nd }} S$ & $1^{\text {st }} \mathrm{S}$ & $2^{\text {nd }} S$ & $1^{\text {st }} \mathrm{S}$ & $2^{\text {nd }} S$ & $1^{\text {st }} \mathrm{S}$ & $2^{\text {nd }} S$ \\
\hline \multicolumn{12}{|c|}{ Effect of locations } \\
\hline \multicolumn{2}{|c|}{ Ras Sudr } & $60.1 \mathrm{a}$ & $60.8 \mathrm{a}$ & $6.06 \mathrm{~b}$ & $5.93 b$ & $85.8 \mathrm{a}$ & $86.8 \mathrm{a}$ & $59.0 \mathrm{a}$ & $59.7 \mathrm{a}$ & $84.3 \mathrm{a}$ & $85.3 \mathrm{a}$ \\
\hline \multicolumn{2}{|c|}{ Al-Maghara } & $60.1 \mathrm{a}$ & $60.8 \mathrm{a}$ & $6.54 a$ & $6.34 \mathrm{a}$ & $85.8 \mathrm{a}$ & $86.8 \mathrm{a}$ & $59.6 \mathrm{a}$ & $60.3 a$ & $85.1 \mathrm{a}$ & $86.1 \mathrm{a}$ \\
\hline \multicolumn{12}{|c|}{ Effect of sowing date } \\
\hline \multicolumn{2}{|c|}{ March $15^{\text {th }}$} & $60.6 \mathrm{a}$ & $61.1 \mathrm{a}$ & $7.85 \mathrm{a}$ & $7.57 \mathrm{a}$ & $86.6 \mathrm{a}$ & $87.3 \mathrm{a}$ & $59.8 \mathrm{a}$ & $60.2 \mathrm{a}$ & $85.4 \mathrm{a}$ & $86.1 \mathrm{a}$ \\
\hline \multicolumn{2}{|c|}{ April $1^{\text {st }}$} & $59.5 \mathrm{a}$ & $60.5 \mathrm{a}$ & $6.74 b$ & $6.59 \mathrm{~b}$ & $85.0 \mathrm{a}$ & $86.5 \mathrm{a}$ & $58.6 \mathrm{a}$ & $59.6 \mathrm{a}$ & $83.8 \mathrm{a}$ & $85.2 \mathrm{a}$ \\
\hline \multicolumn{2}{|c|}{ April $15^{\text {th }}$} & $60.1 \mathrm{a}$ & $60.8 \mathrm{a}$ & $5.69 \mathrm{c}$ & $5.54 \mathrm{c}$ & $85.9 a$ & $86.8 \mathrm{a}$ & $59.4 \mathrm{a}$ & $60.0 \mathrm{a}$ & $84.8 \mathrm{a}$ & $85.7 \mathrm{a}$ \\
\hline \multicolumn{2}{|c|}{ May $1^{\text {st }}$} & $60.0 \mathrm{a}$ & $60.7 \mathrm{a}$ & $4.93 \mathrm{~d}$ & $4.83 \mathrm{~d}$ & $85.7 \mathrm{a}$ & $86.7 \mathrm{a}$ & $59.4 a$ & $60.0 \mathrm{a}$ & $84.8 \mathrm{a}$ & $85.8 \mathrm{a}$ \\
\hline \multicolumn{12}{|c|}{ Effect of interactions } \\
\hline \multirow{4}{*}{$\begin{array}{l}\dot{\Xi} \\
\tilde{E} \\
\mathscr{E} \\
\tilde{E}\end{array}$} & March $15^{\text {th }}$ & $61.0 \mathrm{a}$ & $61.5 \mathrm{a}$ & $7.13 b$ & $6.95 b$ & $87.1 \mathrm{a}$ & $87.9 \mathrm{a}$ & $60.3 \mathrm{a}$ & $60.7 \mathrm{a}$ & $86.1 \mathrm{a}$ & $86.8 \mathrm{a}$ \\
\hline & April $1^{\text {st }}$ & $59.3 \mathrm{a}$ & $60.3 \mathrm{a}$ & $6.28 \mathrm{~d}$ & $6.16 \mathrm{c}$ & $84.6 \mathrm{a}$ & $86.1 \mathrm{a}$ & $58.0 \mathrm{a}$ & $59.0 \mathrm{a}$ & $82.9 \mathrm{a}$ & $84.3 \mathrm{a}$ \\
\hline & April $15^{\text {th }}$ & $60.0 \mathrm{a}$ & $60.6 \mathrm{a}$ & $5.45 \mathrm{fg}$ & 5.26 & $85.7 \mathrm{a}$ & $86.6 \mathrm{a}$ & $58.5 \mathrm{a}$ & $59.1 \mathrm{a}$ & $83.6 \mathrm{a}$ & $84.5 \mathrm{a}$ \\
\hline & May $1^{\text {st }}$ & $60.0 \mathrm{a}$ & $60.7 \mathrm{a}$ & $5.38 \mathrm{~g}$ & $5.34 \mathrm{e}$ & $85.7 \mathrm{a}$ & $86.7 \mathrm{a}$ & $59.3 \mathrm{a}$ & $59.9 \mathrm{a}$ & $84.6 \mathrm{a}$ & $85.6 \mathrm{a}$ \\
\hline \multirow{4}{*}{ 之 } & March $15^{\text {th }}$ & $60.3 a$ & $60.7 \mathrm{a}$ & $8.58 \mathrm{a}$ & $8.18 \mathrm{a}$ & $86.1 \mathrm{a}$ & $86.8 \mathrm{a}$ & $59.3 \mathrm{a}$ & $59.7 \mathrm{a}$ & $84.6 \mathrm{a}$ & $85.3 \mathrm{a}$ \\
\hline & April $1^{\text {st }}$ & $59.8 \mathrm{a}$ & $60.8 \mathrm{a}$ & $7.20 \mathrm{c}$ & $7.02 \mathrm{~b}$ & $85.4 \mathrm{a}$ & $86.8 \mathrm{a}$ & $59.3 \mathrm{a}$ & $60.3 \mathrm{a}$ & $84.6 \mathrm{a}$ & $86.1 \mathrm{a}$ \\
\hline & April $15^{\text {th }}$ & $60.3 \mathrm{a}$ & $60.9 \mathrm{a}$ & $5.93 \mathrm{e}$ & $5.82 \mathrm{~d}$ & $86.1 \mathrm{a}$ & $87.0 \mathrm{a}$ & $60.3 \mathrm{a}$ & $60.9 \mathrm{a}$ & $86.1 \mathrm{a}$ & $87.0 \mathrm{a}$ \\
\hline & May $1^{\text {st }}$ & $60.0 \mathrm{a}$ & $60.7 a$ & $4.48 \mathrm{~h}$ & $4.33 \mathrm{f}$ & $85.7 \mathrm{a}$ & $86.7 \mathrm{a}$ & $59.5 \mathrm{a}$ & $60.2 \mathrm{a}$ & $85.0 \mathrm{a}$ & $86.0 \mathrm{a}$ \\
\hline & $\begin{array}{r}1^{\text {st }} \mathrm{S}= \\
\mathrm{aft} \\
* \mathrm{Me} \\
P \geq\end{array}$ & $\begin{array}{l}\text { season } \\
\text { emerg } \\
\text { laving }\end{array}$ & $2^{\text {nd }} \mathrm{S}=$ & $\begin{array}{l}\text { cond se } \\
\text { ed }\end{array}$ & & $\mathrm{P} / \mathrm{plo}$ & c. $=\mathrm{Nur}$ & ber of $p$ & ts / plot & & \\
\hline
\end{tabular}

With respect to the rest of measurements, expressed as number of plants/plot after the emergency completed, emergency (\%), number of plants/ 
plot after $30^{t}$ days from sowing (survival period $-S_{p}$ ) and survival ratio, as shown in table (4), generally, the treatments had no significant effect during the study growing seasons. These findings may be due to the temperature and adverse environmental conditions wide range that can bottle gourd tolerant (Chimonyo and Modi, 2013).

\section{Effect of Location and Planting Date on Some Vegetative Growth Characteristics}

It is obvious from the data presented in table (5), that the agricultural sites did not show any effect in the studied growth characteristics; expressed as fresh and dry weight per plant in all samples time, which were 30,75 and 120 days from sowing. Except last foliage fresh weight taken after 120 days was significant heavier in Ras Sudr region than Al-Maghara site.

The results in table (5) show clearly that foliage fresh and dry weight in all periods were significantly affected with tested sowing dates and the interaction between agricultural sites and sowing date treatments. Obtained results were true during both successive growing seasons of study.

The planting date treatments showed the plants behavior in photosynthesis process and dry matter accumulation where, showed that FFW and FDW after $30^{\text {th }}$ day were increased with planting delay, the highest values were attributed to the planting in May $1^{\text {st }}$ (last planting date). In the second period, the highest values of FFW and FDW obtained with samples, which were taken after $75^{\text {th }}$ day and recorded in plants planted in April $15^{\text {th }}$, while the increases in the third period were in plants planted in March $15^{\text {th }}$ (the first planting date). The same plants behavior was observed with interaction treatments among planting dates within agricultural sites. The highest values of FFW and FDW was obtained in the first and second samples of transactions in Ras Sudr May $1^{\text {st }}$ and Al-Maghara April $15^{\text {th }}$, respectively. While in the third sample, the highest values were obtained from the first and second planting dates in Ras Sudr and the first planting date in Al-Maghara site, there are no significant differences between them.

Regarding to the absolute growth rate (AGR), it was significantly superior in values actualized from Ras Sudr and earlier planting at March $15^{\text {th }}$, separate or in combination treatments compared with other sites or planting date treatments, during the two successive growing seasons as shown in table (5).

These results agree with those obtained by Martini et al. (2012) and may be due to the difference in the ecosystem in both regions, particularly the maximum and minimum temperatures. Increasing minimum temperatures in the late planting dates leads to increase plant respiration, which reduces dry matter accumulation in the plant tissues, especially in late plants age.

Egyptian J. Desert Res., 66, No. 2, 351-372 (2016) 


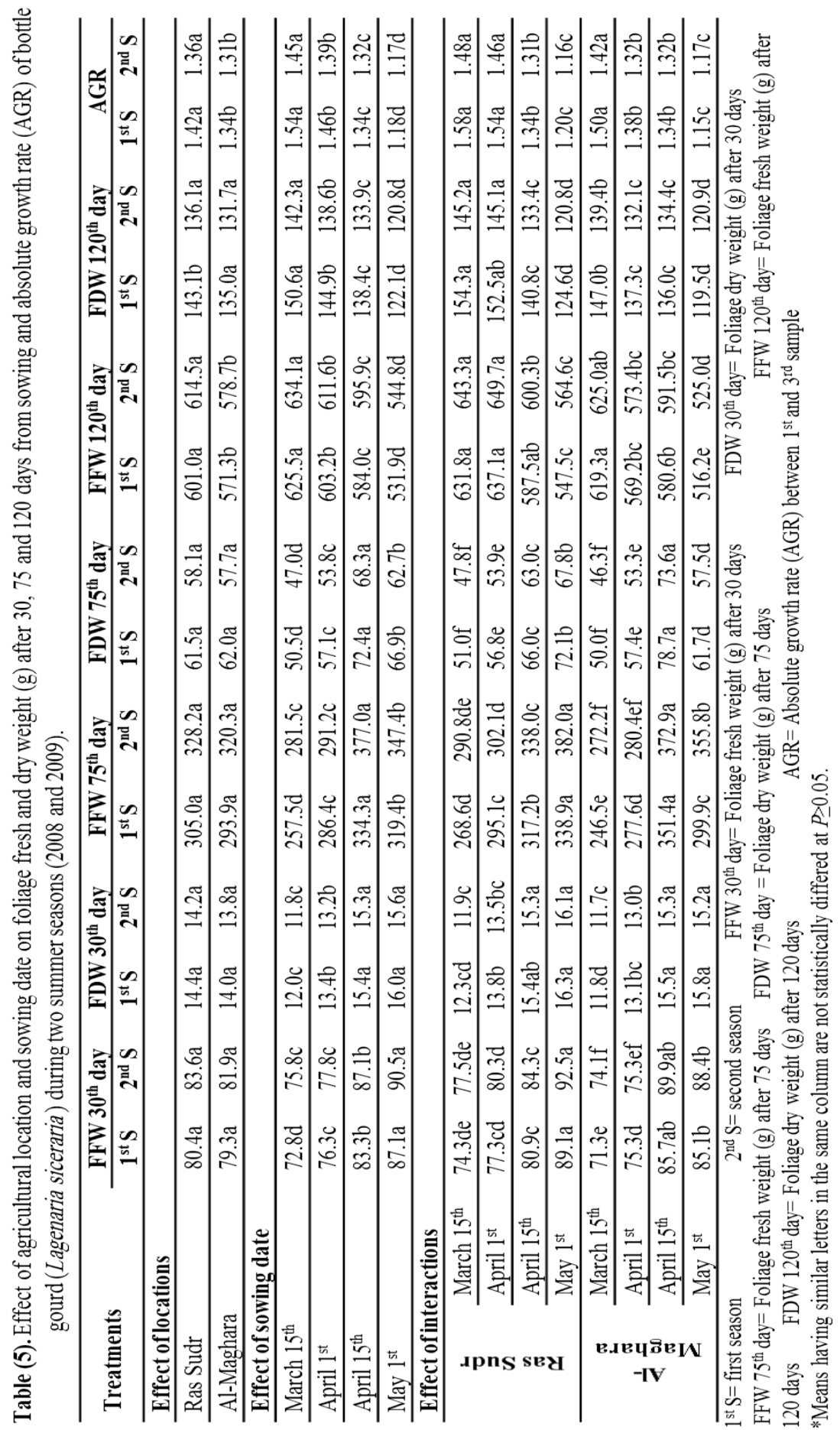

Egyptian J. Desert Res., 66, No. 2, 351-372 (2016) 


\section{Effect of Location and Planting Date on Flowering Characteristics}

Data in table (6) clearly indicate that the agricultural sites did not significantly affect flowering characteristics, i.e. number of days from sowing to first flower (flowering period $F_{p}$ ), number of male flowers $\left(\hat{O}_{s}\right)$, total number of flowers/plant $\left(\hat{O}_{s}+q_{s} / P\right)$, female flowers percentage $(Q \%)$ and sexual ratio $\left(\phi_{s} / \hat{O}_{s}\right)$, except number of female $\left(\phi_{s}\right)$ flowers were significantly increased in Ras Sudr region compared with Al-Maghara site during the two growing seasons.

The data in table (6) clearly indicate that planting dates significantly affected the same characteristics during the two investigated seasons. The highest values of studied items were achieved from plants planted on March $15^{\text {th }}$ while, the lowest values were attributed with delaying planting date.

Regarding to the effect of interaction between agricultural sites and planting dates, the data presented in table (6) show that all investigated characteristics, except $F_{p}$ were significantly affected. The highest increase in no. of $\hat{\partial}_{s}$ and $\hat{\partial}_{s}+q_{s} / P$ was achieved when bottle gourd plants were planted on March $15^{\text {th }}$ in Ras Sudr region, when compared with other treatments. While the planting on March $15^{\text {th }}$ in both Ras Sudr and Al-Maghara significantly increased no. of $Q_{s}, q_{s}(\%)$ and $q_{s} / \hat{O}_{s}$, compared with the other treatments during both growing seasons. These results agree with those obtained by Deshpande et al. (1979), Rasco and Castillo (1990), Huyskens et al. (1992) and Dey et al. (2005).

The results may be due to that pistillate flower of cucurbits production under short photoperiods is increased by low temperatures $\left(20^{\circ} \mathrm{C}\right)$ and night time chilling $\left(25^{\circ} \mathrm{C}\right.$ day $/ 15^{\circ} \mathrm{C}$ night) (Yonemori and Fujieda, 1985).

Sex expression is affected by environmental conditions under which Momondica chorantia seedlings grow (Wang et al., 1997). Short-day cultivars, when grown under short photoperiods, exhibit rapid development and comparatively high gynoecy. To encourage a high frequency of pistillate flowers, short-day treatments should begin at seedling emergence and proceed to sixth-leaf stage (r20 days post emergence under growing optimal conditions). Also, Wang and Zeng (1997) found that pistillate flower number increases as indoleacetic acid (IAA) and zeatin concentration decreases after anthesis.

Many ecological and indigence factors may have effect on the duration plants required to reveal the first flower and flowers number on the same plant. As shown in fig. (1), indigence dry matter accumulation after 30 days from sowing was negative and significant correlated with flowering period. A liner correlation coefficients ( $\mathrm{r}$ ) was -0.94 and the corresponding coefficients of determination $\left(r^{2}\right)$ was 0.88 , this means that $88 \%$ of the variation in the flowering period was related to dry matter accumulation in the plant. The correspondingly regression coefficients (b) was -1.52 , which indicated that each $1 \mathrm{~g}$ of dry matter accumulation in plant decreased the duration plants required to reveal the first flower 1.52 days.

Egyptian J. Desert Res., 66, No. 2, 351-372 (2016) 


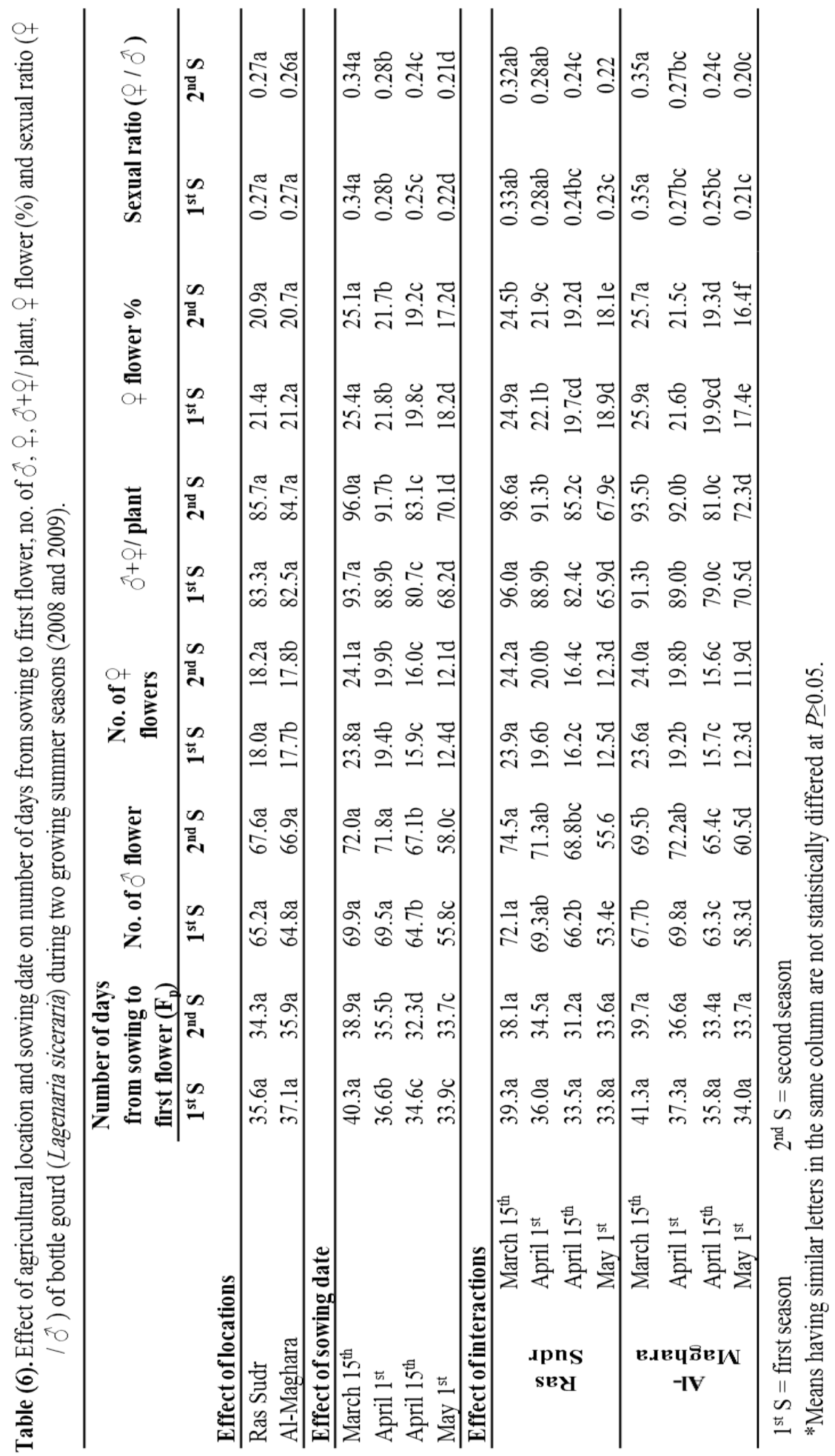

Egyptian J. Desert Res., 66, No. 2, 351-372 (2016) 


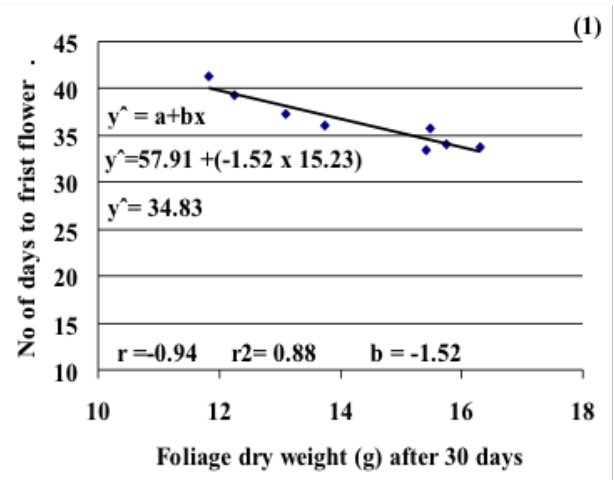

Fig. (1). Correlation coefficient variables related with bottle gourd flowering.

On the contrary, the accumulation of dry matter in plants determined after 120 days from sowing positively correlated with bottle gourd pistillate flowers number per plant, where $r=0.91$, while $r^{2}=0.83$ as well as $b=0.33$.

\section{Effect of Location and Planting Date on Fresh Yield}

Data presented in table (7) show the effect of the agricultural sites and planting dates on bottle gourd characters, i.e., number of days to last fresh fruit, number of fresh fruit/plant, fruit set percentage, average of fresh fruit weight and fruit yield/half plot, as well as fresh fruit yield/fed, during both seasons of the study. Such data refer that, except number of days to last fresh fruit, number of fresh fruit/plant and fruit set percentage, which were not affected, there were significant differences among the used agricultural sites on average of fresh fruit weight, fruit yield/half plot and fresh fruit yield/fed, and the highest values were achieved in Ras Sudr region.

Results showed that plants were planted on earlier planting date significantly increased studied bottle gourd characteristics compared with late planting date, except average fresh fruit weight, which showed opposite direction with the significant highest value on planting date May $1^{\text {st }}$, compared with earlier dates. In addition, results presented in table (7) reveal that all above mentioned fresh fruit yield characteristics were significantly affected with agricultural sites and planting date interaction. The number of days required to get the latest fresh fruit decreased when plants were planted early in Al-Maghara region, while the highest values of both the number of fresh fruits per plant and fruit set percentage were achieved from the plants were planted early with no effect on agricultural sites. The heavy fresh fruit weight was obtained from delay planting date in Ras Sudr region. Finally, the fresh fruit yield, whether $\mathrm{kg} / \mathrm{plot}$ or ton/fed, significantly increased when bottle gourd plants were planted early in Ras Sudr region.

Egyptian J. Desert Res., 66, No. 2, 351-372 (2016)

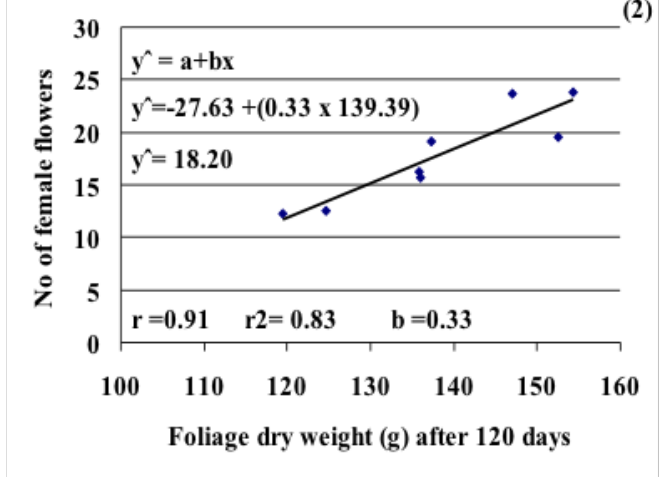

(2)

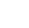




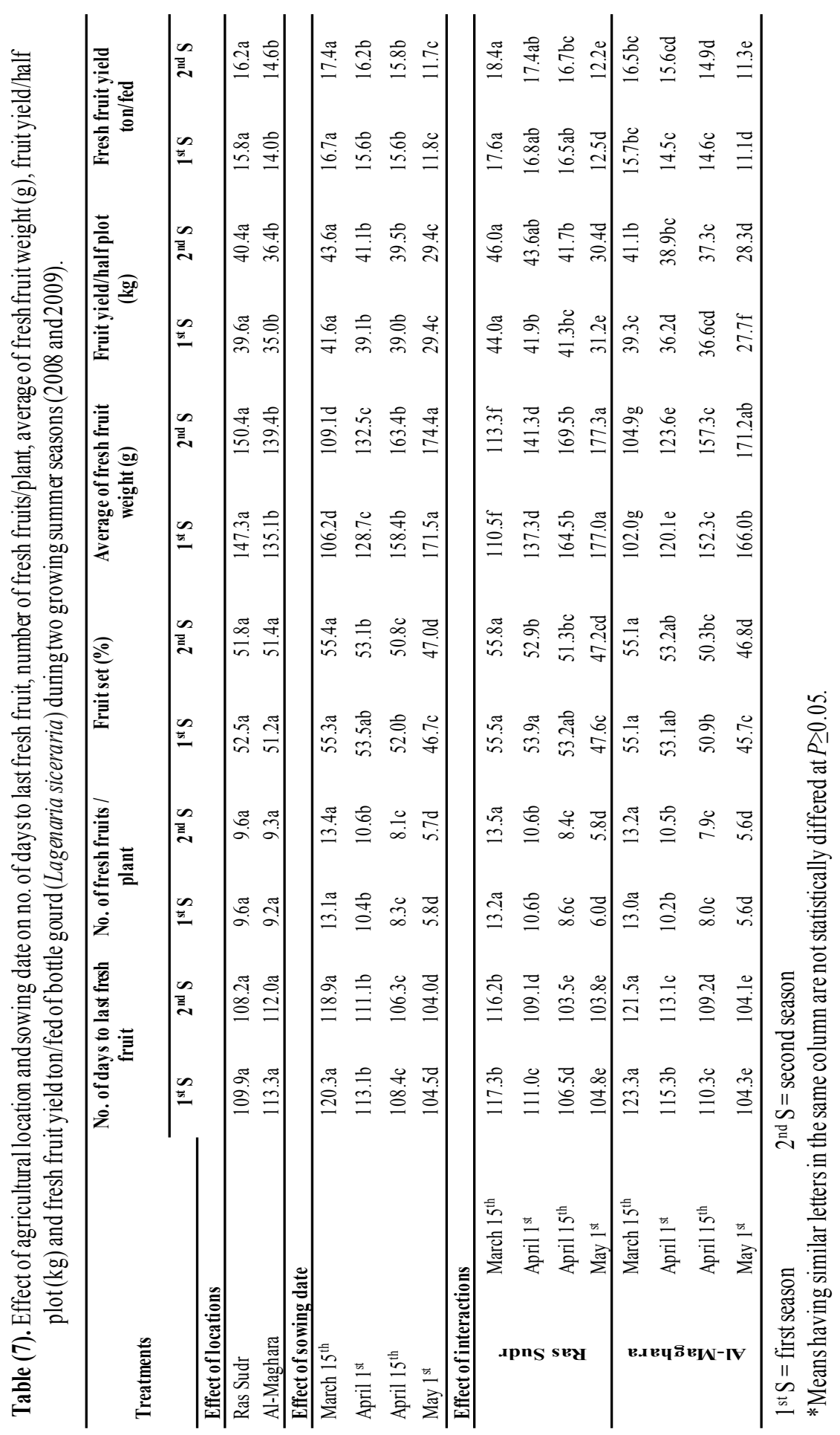

Egyptian J. Desert Res., 66, No. 2, 351-372 (2016) 
These results were true in both demo growing seasons. Similar findings were previously obtained by Haque et al. (2009), who observed bottle gourd yields of $35 \mathrm{t} / \mathrm{ha}$ in sub-tropical to tropical conditions and less than $20 \mathrm{t} / \mathrm{ha}$ in semi-arid conditions.

The increases in fresh fruit yield, as one of research aims, is definitely due to favorable environmental conditions (soil - water quality - climate .... etc.) surrounding vegetation, that led to improve the physiological processes within the plant, which was reflected on the amount of dry matter, number of female flowers and the ability to fertilization. In turn, increased production duration, fruit set (\%) and number of fruits.

It is of interest to disclosure relationships among variables to support interpretation of results. Fig. (2) indicated that, (1) highly significant negative correlation between number of fresh fruit/plant and average of fresh fruit weight (g), a liner correlation coefficient ( $\mathrm{r}$ ) was -0.94 , while the corresponding coefficient of determination $\left(\mathrm{r}^{2}\right)$ was 0.88 . This indicated that $88 \%$ of the variations in fresh fruit weight of bottle gourd were related to number of fresh fruits. The regression coefficient (b) was -9.12 and indicated that each decrease of $9.12 \mathrm{~g}$ of fresh fruit weight, increase one fruit per plant. By the same explanation, (2) increase of one female flower led to increase of 0.64 fresh fruits per plant. (3) increase of one fruit per plant led to increase of 0.63 ton fresh fruit yield per fed.

Regarding the effect of interaction, all recently mentioned measured characteristics significantly increased as affected by agricultural sites and planting dates. The highest number of days needed to complete mature phase was achieved from plants planted in Al-Maghara region on March $15^{\text {th }}$. While the highest seeds number and seeds weight/plant, as well as seeds yield productivity, whether to half plot $\left(10.5 \mathrm{~m}^{2}\right)$ or feddan, were produced from plants planted in Al-Maghara and Ras Sudr on March $15^{\text {th }}$ and first of April. These results agree with those obtained by Odindo (2008) and Chimonyo and Modi (2013).

The seed yield increases may be due to suitable environmental conditions, specially temperature and humidity, which does not adversely affect the flower member, thereby conserving pollen and stigma vitality, which led to the ovules fertilization improvement in torn increased seeds number. In addition, the increases of dry matter accumulation (Table 8) in plant tissues turn into seeds to produce heavy seeds.

Most quality characteristics of seeds have been described as polygenically inherited, and will, therefore, be influenced by the environment, to a large extent (Ye et al., 2003).

\section{Base Temperature and Accumulated Heat Units (Thermal Time $-T_{t}$ )}

It is necessary for plant breeders and producers, especially in food industry field, to know more about base temperature and the accumulated heat units or thermal time as named by some researchers to different plant stages.

Egyptian J. Desert Res., 66, No. 2, 351-372 (2016) 
The number of days and the daily average temperature for first plant growth stage are the basis on which it is estimated base temperature of the plant. The accumulated heat units or thermal time is the summation of heat temperature above base temperature. Calculated base temperature for bottle gourd, Locale cultivar grown at Sinai region, Egypt was $10.88^{\circ} \mathrm{C}\left(51.58^{\circ} \mathrm{F}\right)$. Accumulated heat units above base temperature from seed sowing till the emergence, first flower, last fresh fruit and completely mature phase as affected by sowing date are illustrated in fig. (3). Calculated $\left(\mathrm{T}_{t}\right)$ were 57.2 $\pm 6.6,399.7 \pm 46.6$. $1625 \pm 59.2$ and $2476.0 \pm 20.8$ heat units, respectively, for growth stages mentioned above.
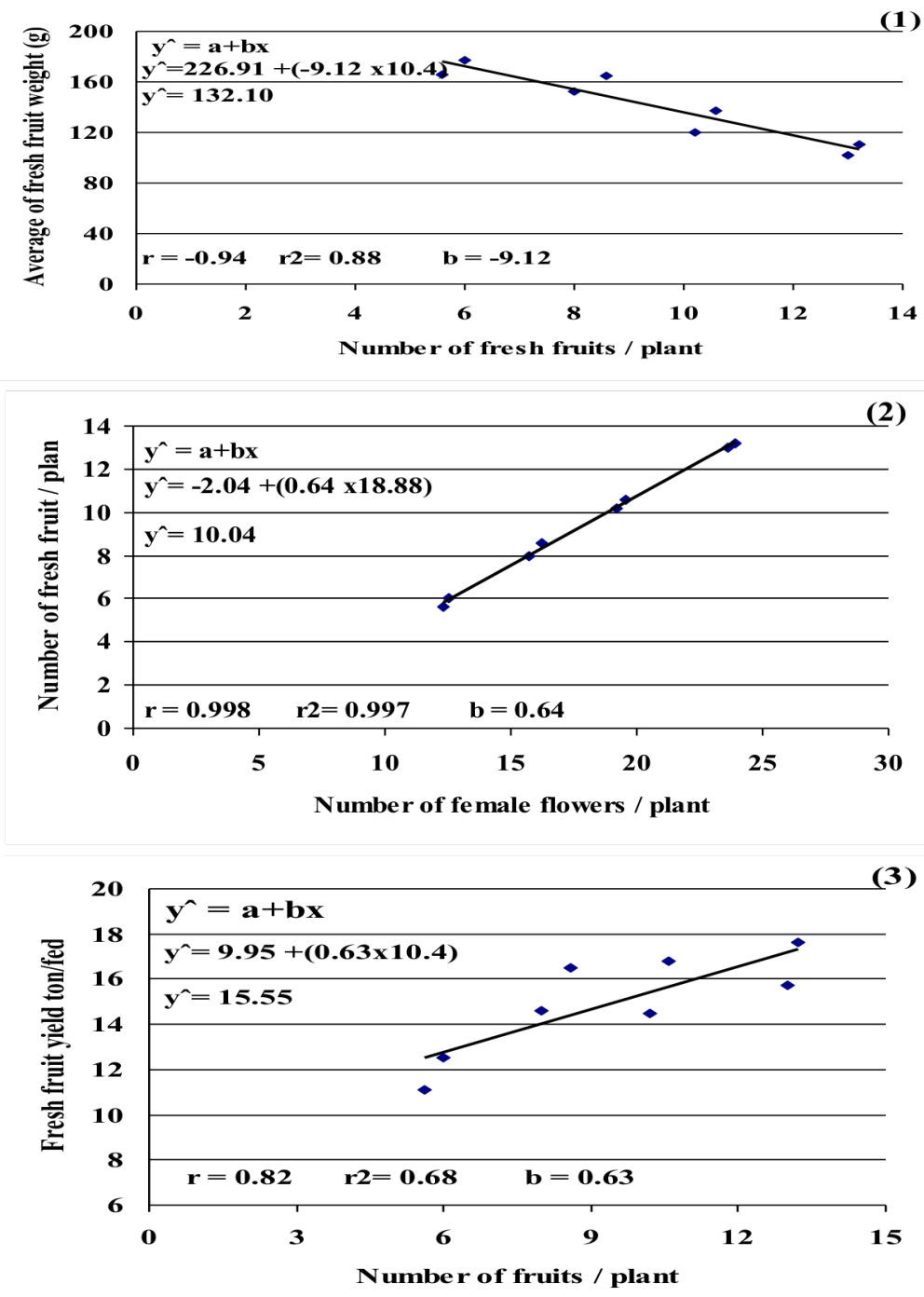

Fig. (2). Correlation coefficient (r), corresponding coefficient of determination $\left(r^{2}\right)$ and regression coefficient (b) liners of some variables related with bottle gourd fresh fruit yield. 


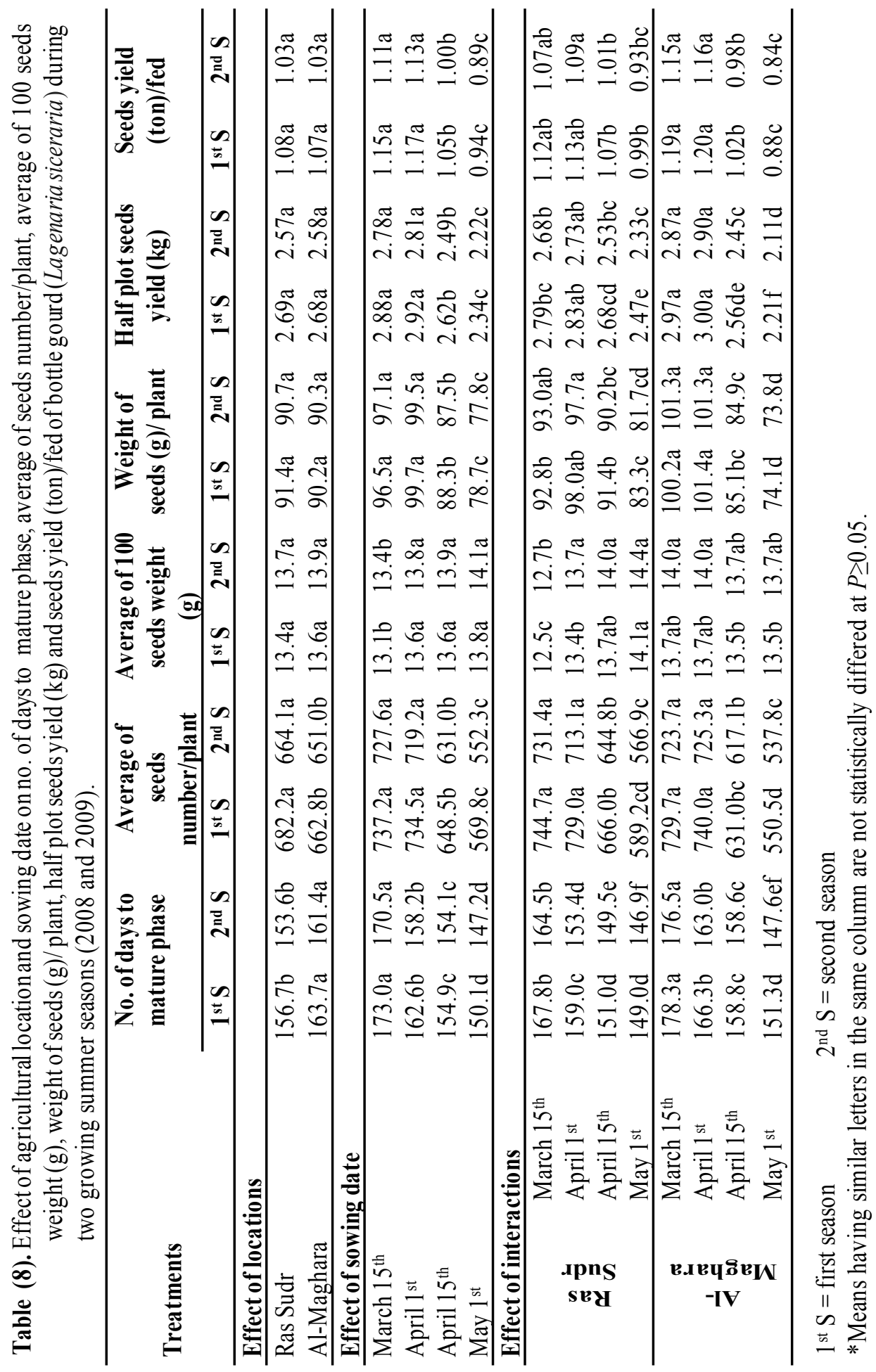

Egyptian J. Desert Res., 66, No. 2, 351-372 (2016) 

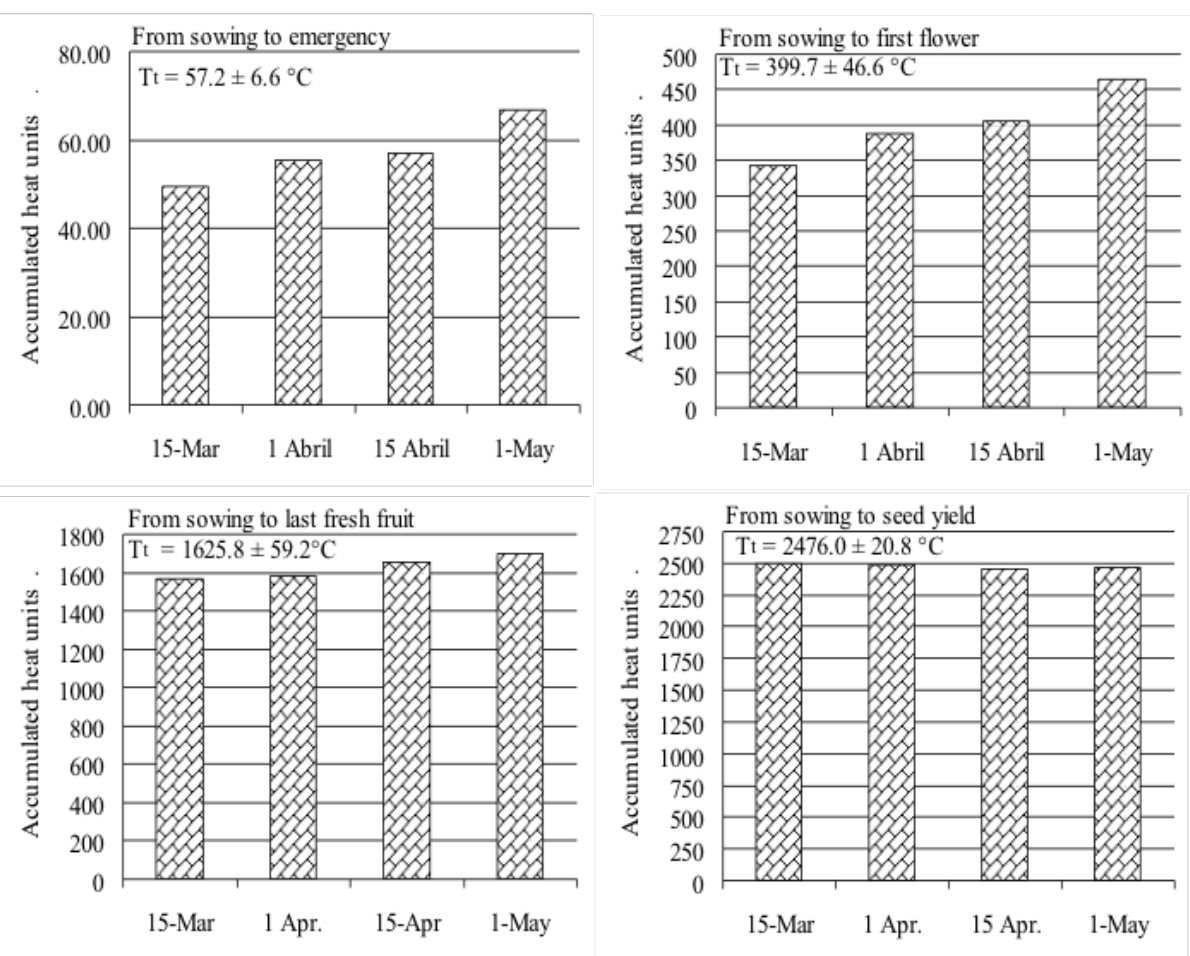

Fig. (3). Accumulated heat units or thermal times $\left(T_{t}\right)$ above base temperature as affected by sowing dates till the emergence, first flower, last fresh fruit and completely mature phases of bottle gourd locale cultivar.

\section{Effect of Location and Planting Date on Nutritional Value}

The effect of agricultural site and sowing dates on nitrogen, phosphorus and potassium concentrations, in addition to the protein and carbohydrate content of bottle gourd fresh fruits are represented in table (9). Data indicated that the agricultural site significantly affected only carbohydrate percentage of fresh fruit. The highest values were obtained from Al-Maghara site. Regarding to sowing dates, plants planted on March $15^{\text {th }}$ contained the highest values of nitrogen, phosphorus and protein in fresh fruits, whereas fruits of plants planted on April $1^{\text {st }}$ contained the highest values of potassium and carbohydrates. As for the interaction effect, it showed that plants sown on the earlier planting dates (March $15^{\text {th }}$ and April $1^{\text {st }}$ ), whether planted in Ras Sudr and Al-Maghara, contained the highest significant values of phosphorus. While, fresh fruits produced from plants planted on the latest sowing dates (April $15^{\text {th }}$ and May $1^{\text {st }}$ ) in both agricultural sites gave the highest concentrations of potassium and carbohydrates. The results were true in both growing seasons. Similar results using okra were obtained by Elhaj and Afrah (2014) and Soubeih (2015). 


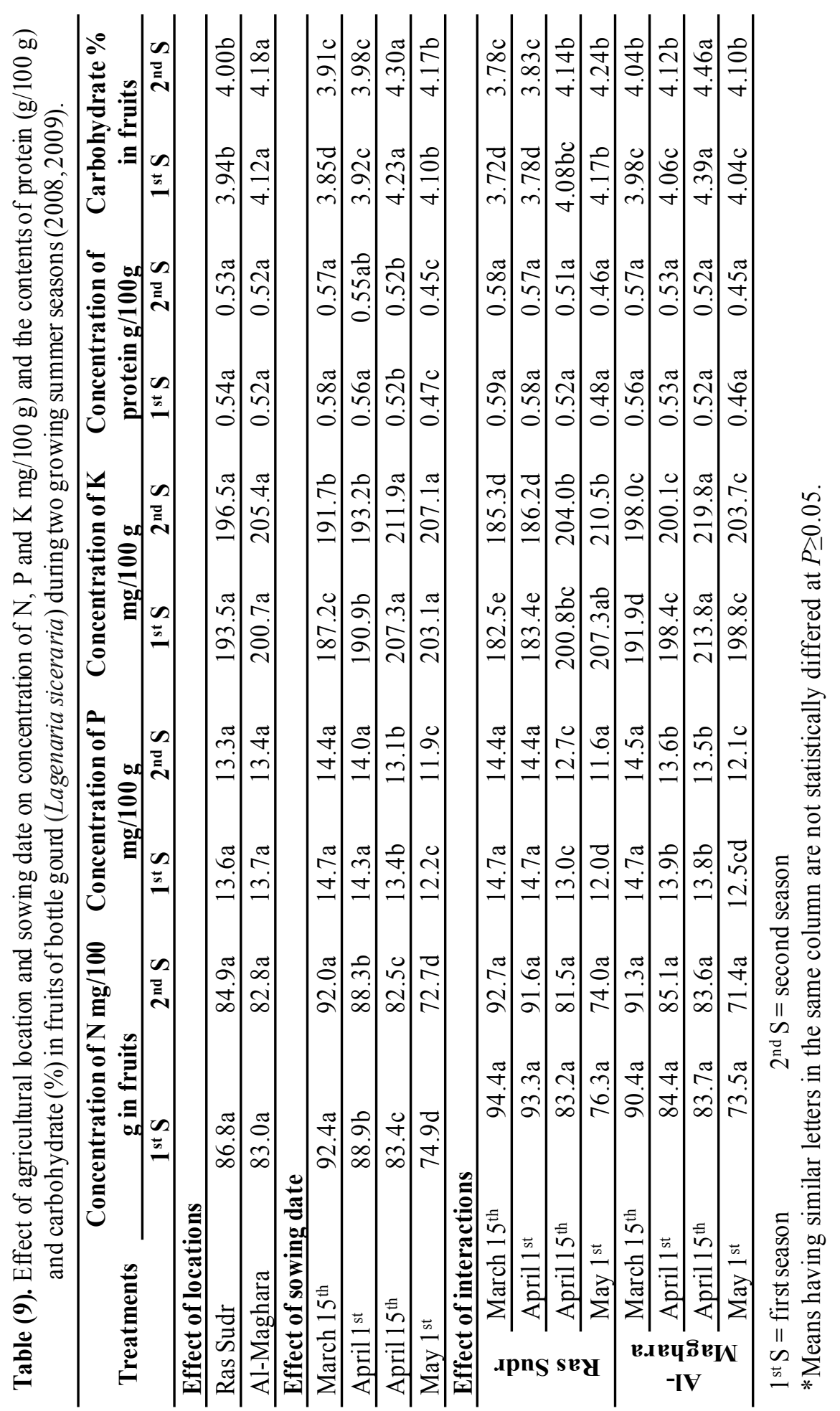

Egyptian J. Desert Res., 66, No. 2, 351-372 (2016) 


\section{CONCLUSION}

It can be concluded that base temperature of bottle gourd grown under varying environmental conditions of Egypt is $10.88^{\circ} \mathrm{C}\left(51.58^{\circ} \mathrm{F}\right)$ and the $\mathrm{T}_{\text {ts }}$ for $75 \%$ of plants emergence, the first flower, last fresh fruit and completely mature phase are $57.6 \pm 6.6,399.7 \pm 46.6,1625 \pm 59.2$ and $2476.0 \pm 20.8$ heat units, respectively. So, it could be produced the highest fresh fruits and seed yields when plants are sowing on March $15^{\text {th }}$.

\section{REFERENCES}

A.O.A.C. (1990). In "Official Methods of Analysis Association of Officinal Analytical Chemists". $16^{\text {th }}$ Ed. Washington, D.C., USA.

Arnold, C.Y. (1959). The determination and significance of the base temperature in a linear heat units system. Proc. Am. Soc. Hort. Sic., 74: $430-445$.

Behera, T.K. (2004). In "Heterosis in Bittergourd". In: Singh, P.K., S.K. Dasgupta and S.K. Thpathi (eds.), Hybrid Vegetable Development. Haworth Press, New York, p. 217-221.

Brown, J.D. and O. Lilliland (1964). Rapid determination of potassium and sodium in plant material and soil extracts flow phosphorus. Proc. Amer. Soc. Hort. Sci., 48: 341-346.

Chaplin, M.F. and J.F. Kennedy (1994). In "Carbohydrates Analysis, A Practical Approach". Oxford Univ. Press, USA, p. 31-32.

Chimonyo, V.G.P. and A.T. Modi (2013). Seed performance of selected bottle gourd (Lagenaria siceraria (Molina) Standl.). American Journal of Experimental Agriculture, 3 (4): 740-766.

Clarke, A.C., K. Burtenshaw, P.A. McLenachan, D.L. Erickson and D. Penny (2006). Reconstructing the origins and dispersal of the Polynesian bottle gourd (Lagenaria siceraria). Mol. Biol. Evol., 23: 893900.

Darabi, A. (2013). Effect of planting date on total and marketable yield of potato cultivars in Khuzestan Province in Iran. Seed and Plant Production Journal, 29 (3): 369-386.

Deshpande, A.A., K. Venkatasubbaiah, V.M. Bankapur and U.G. Nalawadi (1979). Studies on floral biology of bitter gourd (Moinordica charantia L.). Mysore J. Agric. Sci., 13: 156-159.

Dey, S.S., T.K. Batters, A. Pal and A.D. Munshi (2005). Correlation and path coefficient analysis in bitter gourd (Moniordicc charantia L). Veg. Sci., 32: 173-176.

Dubey, R.K., V.S. Kamala and D.K. Kartek (2011). Effect of different planting dates on yield and yield components of potato (Solanum tuberosum) in foot hills of Arunachal Pradesh. Environment and Ecology, 29 (2A): 745-751. 
Elhaj, A.Z. and Afrah, A.A. (2014). Effect of cultivar and sowing date on okra (Abelmoschus esculentus (L.) Moench.) seed yield. Universal Journal of Applied Science, 2 (3): 64-67.

Erickson, D.L., B.D. Smith, A.C. Clarke, D.H. Sandweiss and N. Tuross (2005). An Asian origin for a 10,000-year-old domesticated plant in the Americas. Proc. Natl. Acad. Sci., 102 (18): 315-320.

Frie, E., K. Peyer and E. Schultz1 (1964). Determination of phosphorus by ascorbic acid. Schw. Landwirtschaft Forshung Heft, 3: 318- 328.

Gomaa, S.S. (2014). Effect of planting dates and seed tuber sources on productivity of potato in Siwa Oasis. J. Plant Productivity, Mansoura Univ., 5 (12): 2001-2016.

Gomez, K.A. and A.A. Gomez (1984). In "Statistical Procedures for Agricultural Research". Second Ed. Wiely Interscience Publ. John I. Willey and Sons, New York.

Haque, M.M., M. Hasanuzzaman and M.L. Rahman (2009). Effect of light intensity on the morphophysiology and yield of bottle gourd (Lagenaria vulgaris). Acta J. Plant Sci., 2 (3):158-161.

Hossain, A., J.A.T. Silva, M.V. Lozovskaya and V.P. Zvolinsky (2012). The effect of high temperature stress on the phenology, growth and yield of five wheat (Triricum aestivum L.) varieties. The Asian and Australasian Journal of Plant Science and Biotechnology, 6 (1): $14-23$.

Huyskens, S., S. Mendlinger, A. Benzioni and M. Ventura (1992). Optimization of agrotechniques for cultivating Momordica charantia (Karela). J. Hort. Sci., 67: 259-264.

Jackson, M.E. (1962). In "Soil Chemical Analysis". Constable and Company Ltd., London, pp. 448.

Martini, M.Y., B.A. McKenzie, D.J. Moot and G.D. Hill (2012). Dry matter accumulation of faba bean sown at different sowing dates in Canterbury. Agronomy New Zealand, 42: 43-51.

Milind, P. and K. Satbir (2011). Is bottle gourd a natural guard?. Int. Res. J. Pharm., 2 (6): 13-17.

Odindo, A.O. (2008). Cowpea seed quality in response to production site and water stress. Ph.D. Thesis, University of Kwa Zulu Natal, Pietermaritsburg.

Peach, K. and M.R. Tracey (1959). In "Modern Methods of Plant Analysis". Vol. 1, Springer Verlage, Berlin, 4: 643.

Piper, S.C.S. (1950). In "Soil and Plant Analysis". Univ. Inter. Sci. Publishers, Inc., New York, Adelaide, p. 258-275.

Radford, P.J. (1967). Growth analysis formulae-their use and abuse. Crop Sci., 7: 171-175.

Egyptian J. Desert Res., 66, No. 2, 351-372 (2016) 
Rasco, A.O. and P.S. Castillo (1990). Flowering patterns and vine pruning effects in bittergourd (Momordico charontia U.) varieties 'Sta. Rita' and 'MaUling'. Philippine Agr., 73: 3-4.

Richards, L.F. (1954). "Diagnosis and Improvement of Saline and Alkaline Soils". Agric. Hand Book, USA, pp. 60.

Richardson, J.B. (1972). III. The pre-Colombian distribution of the bottle gourd (Lagenaria siceraria): A re-evaluation. Econ. Bot., 26: 265-273.

Sawicka, B. and B. Marczak (2011). Ecological aspects of potato cultivation in Strzyzowsko-Dynowskie Foothills. Biuletyn Instytutu Hodowli i Aklimatyzacji Roslin, 259: 229-242.

Schlumbaum, A. and P.A. Vandorpe (2012). Short history of Lagenaria siceraria (bottle gourd) in the Roman provinces: morphotypes and archaeogenetics. Veget. Hist. Archaeobot., 21: 499-509.

Sillitoe, P. (2003). Natural resources exploited by the Wola in the manufacture of artifacts. Sci. in New Guinea.10: 112-133. (C.F. Chimonyo and Modi, 2013).

Soubeih, Kh.A.A. (2015). Some agricultural treatments for Okra (Abelmoschus esculentus L.) Production under Low Temperature Conditions. J. Plant Productivity, Mansoura Univ., 6 (10).

Wang, Q.M. and G.W. Zang (1997). Hormonal regulation of sex differentiation on Moinordica charontia L. J. Zhejiang Agr. Univ., 23: 551-556.

Wang, Q.M., G.W. Zang and Y.T. Jiang (1997). Effects of temperature and photoperiod on sex expression of Mornordica chararitia. China Vegetables, 1: 1-4.

Ye, Z, Z.Z. Lu and J. Zhu (2003). Genetic analysis for developmental behavior of some seed quality traits in upland cotton (Gossypum hirsutum L.). Euphytica, 129: 183-191.

Yonemori, S. and K. Fujieda (1985). Sex expression in Momondica chorantia L. Science Bulletin of the College of Agriculture, University of the Rynkyus, Okinawa, 32: 183-187. 


\section{تأثثير الموقع وميعاد الزراعة على إنتاجية اليقطين في الأراضي الصحراوية}

خالد عوض الله أحمد صبيح

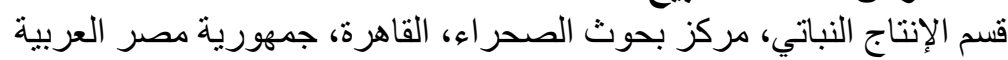

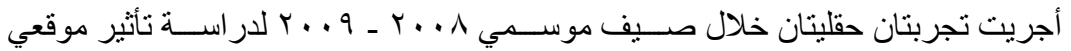

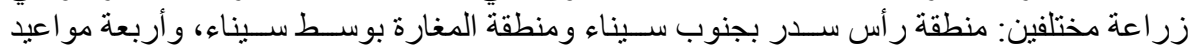

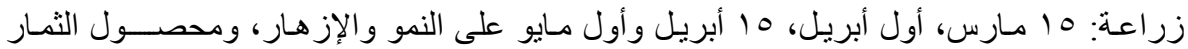

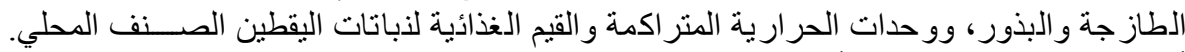

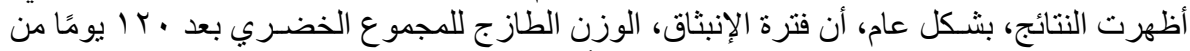

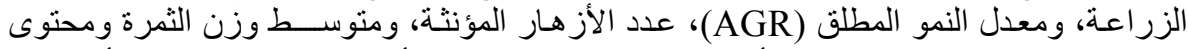

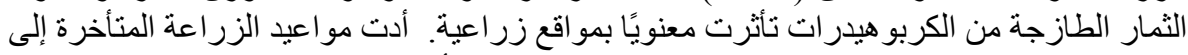

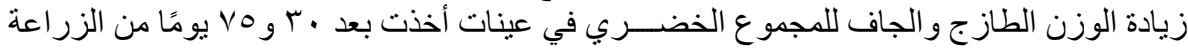

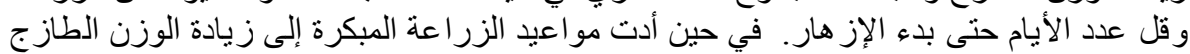

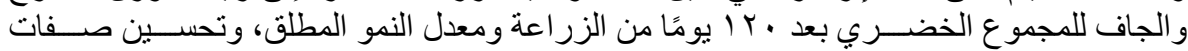

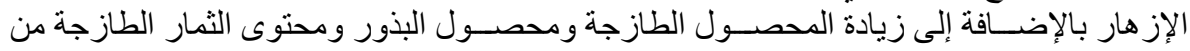

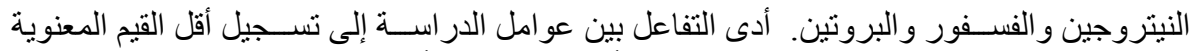

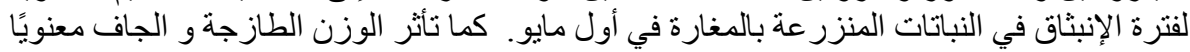

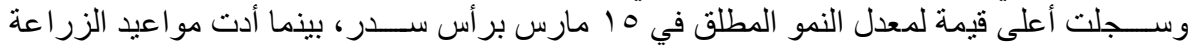

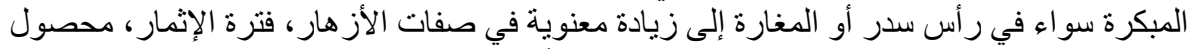

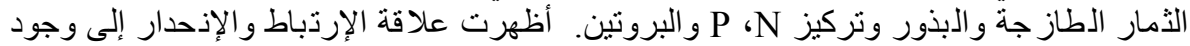

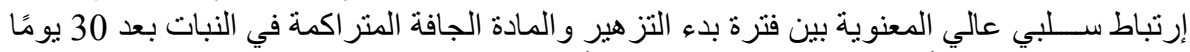

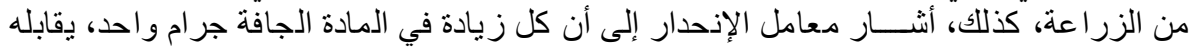

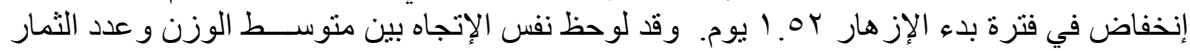

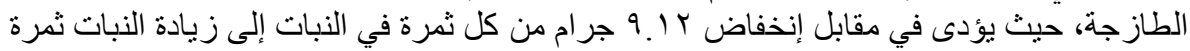

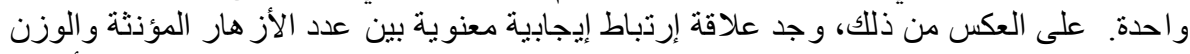

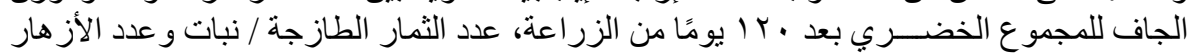

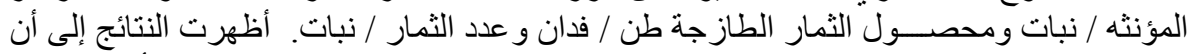

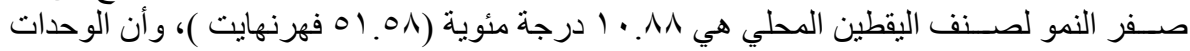

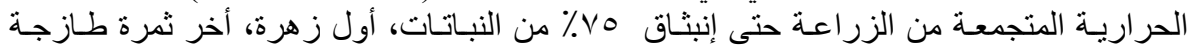

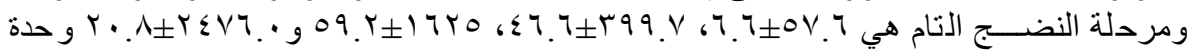

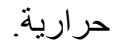

Egyptian J. Desert Res., 66, No. 2, 351-372 (2016) 